\title{
RISIKO KENAIKAN HEMATOKRIT TERHADAP TERJADINYA RENJATAN PADA KASUS DEMAM BERDARAH DENGUE
}

\section{(RISK OF HEMATOCRIT INCREASED WHERE SHOCK OCCURS ON DENGUE HEMORRHAGIC FEVER)}

\author{
Sumakto, Nurtjahjo Budi Santoso, Susanto Nugroho, Siti Lintang Kawurjan \\ Laboratorium/SMF IImu Kesehatan Anak \\ FK Unibraw/RSU dr. Saiful Anwar Malang
}

\begin{abstract}
Shock is life threatening feature of DHF it must be manage properly through close clinical and laboratory observations. This was a pre-eliminary study to evaluate hematocrit (Hct) increased where shock occurs on dengue hemorrhagic fever (DHF) or dengue shock syndrome (DSS). The WHO criteria was used to diagnose DHF, with two or more clinical criteria with trombocytopenia $(\leq 100.000)$ and Hct increase $\geq 20 \%$. Examination of hemoglobin (Hb), Hct, thrombocytes and leucocytes were done in RSU Dr. Saiful Anwar Central Laboratory everyday during hospitalized. The increase of Hct percentage and $\mathrm{Hct} / \mathrm{Hb}$ ratio calculation were based on the result of lowest dan highest $\mathrm{Hct}$ and $\mathrm{Hb}$ examination. The data obtains was analysed with t-test using SPSS version 10.0 programme. From 30 DHF cases, $23(76.66 \%)$ non DSS and 7 (23.77\%) DSS. The average Hct increase in all patients from serial examinations was $21.09 \%$ ( $S D=2.32 \%)$. However, in 7 DSS patients the average Hct increase was $23.79 \%(S D=3.84 \%)$ higher than the 23 non DSS patients (20.28\%; $S D=0.25 \%$ ). It was observed that the Hct increase in DSS patients was higher than that for non DSS patients. This high Hct level of $23.79 \%$ increases the likelihood of shock by 2.5 times compare with an Hct rise of $20.28 \%$. There was a significant difference in the highest and lowest $H c t / H b$ ratio between DSS and non DSS cases $(p=0.000)$.
\end{abstract}

Keywords : dengue hemorrhagic fever, dengue shock syndrome, hematocrit increase, $\mathrm{Hct} / \mathrm{Hb}$ ratio

\section{PENDAHULUAN}

Penyakit demam berdarah dengue (DBD) sampai saat ini masih merupakan salah satu masalah kesehatan masyarakat di Indonesia. DBD adalah penyakit infeksi akut yang disebabkan oleh virus dengue dan ditularkan oleh nyamuk Aedes aegypti. Jumlah kasus dan penyebaran DBD menunjukkan peningkatan setiap tahunnya, meskipun angka kematian cenderung menurun. Diagnosis dini dan pemantauan yang cermat baik klinis maupun laboratoris sangat menentukan keberhasilan dalam penanganan kasus DBD (1).

Infeksi virus dengue pada manusia mengakibatkan spektrum klinis bervariasi, mulai dari yang paling ringan berupa demam tidak spesifik (undifferentiated febrile illness), demam dengue (DD) sampai bentuk yang lebih berat yaitu DBD dan sindrom syok dengue (SSD) $(1,2)$.

Patogenesis terjadinya DBD yang paling banyak dianut adalah the secondary heterologous dengue infection atau the sequential dengue infection, dimana DBD akan terjadi apabila seseorang terinfeksi kedua kalinya oleh virus dengue dengan serotipe yang berbeda. Perubahan utama patofisiologi yang terjadi pada DBD adalah vaskulopati, trombopati, koagulopati dan perubahan imunologi humoral dan seluler. Diperkirakan perubahan tersebut tidak hanya oleh satu faktor, tetapi multifaktorial. Aktivasi sistem komplemen oleh kompleks virusantibodi akan merangsang pelepasan zat anafilatoksin (C3a, C5a) sebagai mediator kuat yang menyebabkan permeabilitas kapiler

Jurnal Kedokteran Brawijaya, Vol. XX, No.2, Agustus 2004.

Korespondensi: Dr. Sumakto, Sp.A; Laboratorium/SMF IImu Kesehatan Anak FK Unibraw/RSU Dr. Saiful Anwar; Jl. Jaksa Agung Soeprapto 2; Telp.(0341) 343343, Fax.(0341) 369393

Malang - 65111 meningkat dan kebocoran plasma (Gambar 1) (3). Yang membedakan DBD dengan DD adalah ditemukannya kebocoran plasma, yang ditandai salah satunya dengan hemokonsentrasi atau peningkatan hematokrit $(\mathrm{Ht}) 20 \%$ atau lebih. Kebocoran plasma menyebabkan hipovolemia dan dapat berlanjut menjadi renjatan. Disamping perdarahan, renjatan hipovolemik merupakan penyebab kematian pada DBD. Bila tidak diatasi secara tepat, renjatan akan berkepanjangan atau berulang, sehingga terjadi hipoksia berat yang memicu timbulnya disseminated intravascular coagulopthy (DIC) yang menyebabkan perdarahan masif $(1,2,3)$.

Kriteria diagnosis DBD menurut WHO (1999) berdasarkan gejala klinis dan laboratorium. Ditemukannya dua atau lebih kriteria klinis disertai trombositopenia dan hemokonsentrasi sudah cukup untuk menegakkan diagnosis DBD. Dengan kriteria ini, $87 \%$ kasus tersangka DBD dapat didiagnosis dengan tepat, yang dibuktikan dengan pemeriksaan serologis, dan dapat dihindari penentuan diagnosis secara berlebihan $(1,2)$.

Menurut Sutaryo, prioritas yang perlu dikembangkan dalam penatalaksanaan DBD di Indonesia berdasarkan kepraktisannya adalah tehnik pemeriksaan trombosit, hematokrit, limfosit plasma biru, dan apabila mungkin hemaglutination inhibition (HI) test atau Dot blot IgM dan IgG (4). Oleh karena itu, untuk mengetahui terjadinya renjatan lebih dini diperlukan pemantauan klinis dan laboratorium yang ketat, sehingga pengelolaan cairan dapat lebih tepat $(4,5,6)$.

Tujuan penelitian ini adalah untuk menilai risiko kenaikan $\mathrm{Ht}$ terhadap terjadinya renjatan pada kasus DBD. Dengan demikian, ditemukannya peningkatan $\mathrm{Ht}$ (hemokonsentrasi) yang bermakna diharapkan dapat meningkatkan kewaspadaan dalam penatalaksanaan DBD, khususnya dalam pengelolaan cairan. 


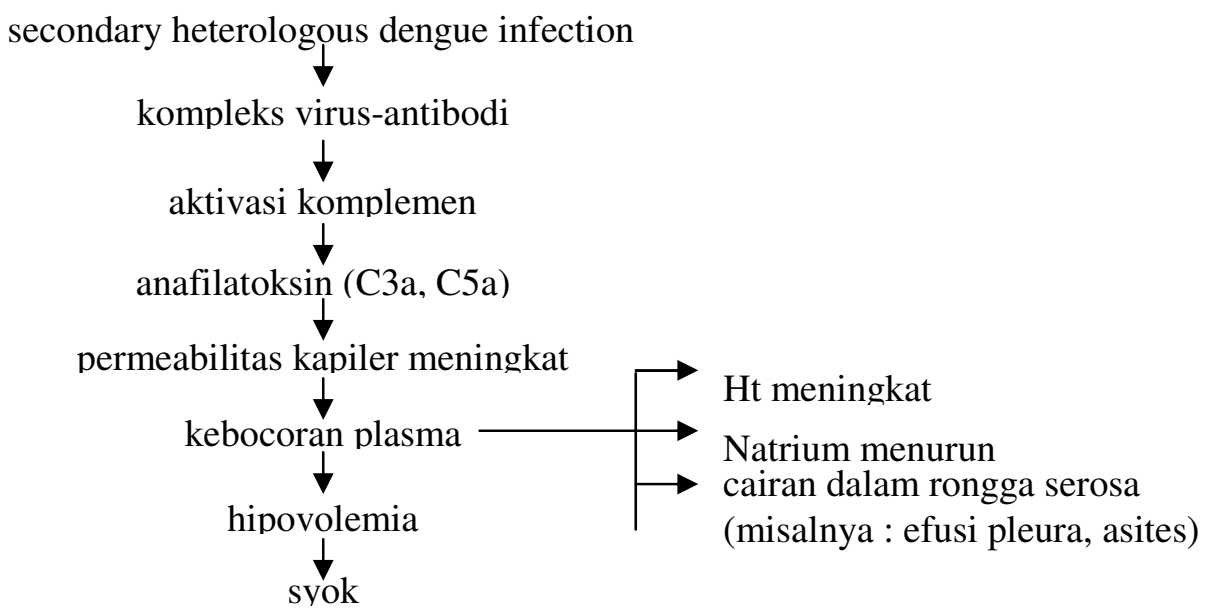

Gambar 1. Patogenesis terjadinya renjatan pada DBD (3)

\section{METODE}

Kasus DBD diambil dari penderita anak yang dirawat di Bagian IImu Kesehatan Anak RSU Dr. Saiful Anwar Malang. Diagnosis DBD ditegakkan berdasarkan kriteria WHO (1999) yaitu ditemukannya dua atau lebih kriteria klinis disertai trombositopenia dan hemokonsentrasi (peningkatan $\mathrm{Ht}$ ). Penderita didiagnosis sindrom syok dengue (SSD) apabila ditemukan tanda-tanda kegagalan sirkulasi atau renjatan, antara lain takikardi, nadi cepat dan lemah, tekanan nadi menyempit (20 $\mathrm{mmHg}$ atau kurang), akral dingin, oliguria, dan hipotensi.

Pemeriksaan darah rutin, meliputi $\mathrm{Hb}, \mathrm{Ht}$, trombosit dan leukosit dilakukan setiap hari selama penderita dirawat. Pemeriksaan laboratorium dilakukan di laboratorium sentral RSU Dr. Saiful Anwar Malang. Persentase kenaikan $\mathrm{Ht}$ dan rasio $\mathrm{Ht} / \mathrm{Hb}$ dihitung berdasarkan hasil pencatatan serial nilai $\mathrm{Ht}$ dan $\mathrm{Hb}$ yang tertinggi dan terendah selama perawatan.

Dari data yang terkumpul dilakukan tabulasi dan analisis dengan $t$-test menggunakan program SPSS versi 10.0.

\section{HASIL PENELITIAN}

Sebanyak 30 penderita DBD anak berusia 3-13 tahun diikutkan dalam penelitian ini, terdiri dari 14 laki-laki (46,66\%) dan
16 perempuan $(53,34 \%)$. Tujuh dari 30 penderita $(23,3 \%)$ dengan syok atau sindrom syok dengue (SSD) dan 23 penderita $(76,7 \%)$ tanpa syok (Tabel 1).

Tabel 1. Data penderita SSD dan non SSD menurut jenis kelamin

\begin{tabular}{lrrr}
\hline \multirow{2}{*}{ Diagnosis } & \multicolumn{2}{c}{ Jenis kelamin } & \multicolumn{1}{c}{ Jumlah } \\
\cline { 2 - 3 } \cline { 2 - 3 } & Laki-laki & Perempuan & \multicolumn{1}{l}{$7(23,3 \%)$} \\
SSD & 4 & 3 & $23(76,7 \%)$ \\
Non SSD & 10 & 13 & $30(100 \%)$ \\
Jumlah & 14 & 16 & \\
\hline
\end{tabular}

Pada pemeriksaan darah rutin waktu penderita mulai dirawat didapatkan nilai $\mathrm{Ht}$ minimum dan maksimum pada kasus non SSD adalah 28,00 dan 38,50; sedangkan pada SSD adalah 30,90 dan 37,70. Hasil pemeriksaan serial berikutnya menunjukkan nilai $\mathrm{Ht}$ minimum dan maksimum pada kasus non SSD sebesar 33,70 dan 46,30; sedangkan pada kasus SSD sebesar 37,10 dan 45,50 (Tabel 2).

Tabel 2. Nilai minimum dan maksimum $\mathrm{Hb}$ dan $\mathrm{Ht}$ pada dua kali pemeriksaan

\begin{tabular}{lllllllll}
\hline \multirow{2}{*}{ Diagnosis } & \multicolumn{2}{c}{ Nilai Hb 1 } & \multicolumn{2}{c}{ Nilai Hb 2 } & \multicolumn{2}{c}{ Ht 1 } & \multicolumn{2}{c}{ Nilai Ht 2 } \\
\cline { 2 - 9 } & \multicolumn{1}{c}{ Min } & Maks & Min & Maks & Min & Maks & Min & Maks \\
\hline SSD & 10,10 & 12,50 & 10,10 & 13,00 & 30,90 & 37,70 & 37,10 & 45,50 \\
Non SSD & 9,30 & 13,00 & 9,50 & 13,30 & 28,00 & 38,50 & 33,70 & 46,30 \\
\hline
\end{tabular}

Keterangan : min (minimum), maks (maksimum)

Dari nilai $\mathrm{Ht}$ minimum dan maksimum didapatkan rerata kenaikan $\mathrm{Ht}$ dari nilai $\mathrm{Ht}$ tertinggi dan terendah pada pemeriksaan serial seluruh penderita sebesar $21,09 \%(\mathrm{SD}=2,32 \%)$. Pada 7 penderita SSD didapatkan rerata kenaikan hematokrit lebih tinggi yaitu $23,79 \%$ ( $S D=3,84 \%$ ) dibandingkan pada 23 penderita non SSD yaitu sebesar $20,28 \%(S D=0,25)$ (Tabel 3 ).
Berdasarkan rasio $\mathrm{Ht} / \mathrm{Hb}$ pada dua kali pemeriksaan didapatkan kenaikan rasio $\mathrm{Ht} / \mathrm{Hb}$ yang lebih tinggi pada penderita SSD dibandingkan non SSD. Pada 7 penderita SSD didapatkan rerata rasio $\mathrm{Ht} 1 / \mathrm{Hb} 1$ sebesar $3,06(\mathrm{SD}=0,04)$ dan rerata rasio $\mathrm{Ht}$ $2 / \mathrm{Hb} 2$ sebesar $3,70(\mathrm{SD}=0,15)$. Sedangkan pada 23 penderita non SSD, rerata rasio $\mathrm{Ht} 1 / \mathrm{Hb} 1$ sebesar $3,02(S D=0,04)$ dan rerata rasio $\mathrm{Ht} 2 / \mathrm{Hb} 2$ sebesar 3,59 (SD=0,09) (Tabel 4). 
Tabel 3. Rerata nilai $\mathrm{Ht}$ 1, Ht2 dan kenaikan $\mathrm{Ht}$ pada penderita SSD dan non SSD

\begin{tabular}{lccc}
\hline \multicolumn{1}{c}{ Diagnosis } & Rerata nilai Ht 1 & Rerata nilai Ht 2 & Rerata kenaikan Ht \\
& $(\mathrm{SD})$ & $(\mathrm{SD})$ & $(\mathrm{SD})$ \\
\hline SSD & $33,84(2,77)$ & $41,84(2,87)$ & $23,79(3,84)$ \\
Non SSD & $33,35(3,31)$ & $40,11(3,96)$ & $20,28(0,25)$ \\
SDD \& Non SSD & $33,47(3,15)$ & $40,52(3,76)$ & $21,09(2,32)$ \\
\hline
\end{tabular}

Keterangan : nilai $O . R .=2,59$ (C.I.95\% 0,23-1,96); SD (standar deviasi)

Tabel 4. Rerata rasio $\mathrm{Ht} 1 / \mathrm{Hb} 1$ dan $\mathrm{Ht}$ 2/Hb 2 pada penderita SSD dan non SSD

\begin{tabular}{lcc}
\hline \multicolumn{1}{c}{ Diagnosis } & $\begin{array}{c}\text { Rerata rasio } \mathrm{Ht} \mathrm{1/Hb} \mathrm{1} \\
(\mathrm{SD})\end{array}$ & $\begin{array}{c}\text { Rerata rasio } \mathrm{Ht} 2 / \mathrm{Hb} 2 \\
(\mathrm{SD})\end{array}$ \\
\hline SSD & $3,06(0,04)$ & $3,70(0,15)$ \\
Non SSD & $3,02(0,04)$ & $3,59(0,09)$ \\
SDD \& Non SSD & $3,03(0,04)$ & $3,62(0,12)$ \\
\hline & $p=0,000$ & $p=0.000$ \\
\hline
\end{tabular}

\section{DISKUSI}

Seperti tampak pada Tabel 1, kejadian renjatan pada 30 kasus DBD yang dirawat di Bagian IImu Kesehatan Anak RSU Dr. Saiful Anwar Malang adalah 23,3\%. Data yang diperoleh ini lebih rendah dibandingkan dengan beberapa hasil penelitian lainnya dimana kejadian renjatan ditemukan sebesar $27,7-34,3 \%$ dari seluruh kasus DBD $(1,4,5,6)$. Distribusi penderita DBD berdasarkan jenis kelamin tidak menunjukkan perbedaan bermakna pada penderita laki-laki maupun perempuan. Hasil ini mendukung beberapa hasil penelitian lainnya yang menyatakan bahwa tidak ada perbedaan yang bermakna kejadian DBD atau DSS pada anak laki-laki maupun perempuan $(1,6)$.

Sedangkan Tabel 2 dan 3 menunjukkan, bahwa nilai $\mathrm{Ht}$ minimum dari dua kali pemeriksaan darah serial pada kelompok penderita SSD lebih tinggi dibandingkan non SSD, sebaliknya dengan nilai $\mathrm{Ht}$ maksimum pada non SSD lebih tinggi dibandingkan SSD. Berdasarkan nilai $\mathrm{Ht}$ minimum dan maksimum tersebut dapat ditentukan rerata kenaikan $\mathrm{Ht}$, yang diharapkan dapat memprediksikan terjadinya syok pada penderita DBD. Hasil analisis statistik rerata kenaikan $\mathrm{Ht}$ pada kasus SSD dan non SSD menunjukkan O.R. sebesar 2,59 (C.I.95\% 0,23-1,96), sehingga dapat diartikan bahwa pada rerata kenaikan persentase $\mathrm{Ht}$ $23,79 \%$ penderita berisiko lebih dari 2,5 kali untuk mengalami renjatan dibandingkan bila rerata persentase $\mathrm{Ht}$ sebesar 20,28\%

Dapat dilihat pada Tabel 4, bahwa rerata rasio $\mathrm{Ht} / \mathrm{Hb}$ minimum dan maksimum pada kasus SSD dan non SSD menunjukkan perbedaan yang sangat bermakna $(p=0,000)$. Hasil analisis statistik menunjukkan bahwa rasio $\mathrm{Ht} / \mathrm{Hb}$ yang semakin tinggi pada pemeriksaan darah serial meningkatkan risiko terjadinya renjatan pada kasus DBD. Tetapi masih diperlukan penelitian lebih lanjut dengan sampel lebih besar dan pemeriksaan serial lebih banyak untuk menentukan cut of point (titik potong) rasio $\mathrm{Ht} / \mathrm{Hb}$ yang dapat menggambarkan terjadinya renjatan pada DBD.

\section{KESIMPULAN}

Terdapat kenaikan $\mathrm{Ht}$ yang lebih tinggi pada SSD (23,79\%; SD $=3,84 \%)$ dibandingkan pada non SSD $(20,28 \%$; $\mathrm{SD}=0,25)$. Kenaikan persentase $\mathrm{Ht} 23,79 \%$ memberikan risiko pada penderita DBD lebih dari 2,5 kali untuk mengalami renjatan dibandingkan bila kenaikan persentase $\mathrm{Ht}$ sebesar 20,28\%.

Terdapat kenaikan rasio $\mathrm{Ht} / \mathrm{Hb}$ yang lebih tinggi pada penderita SSD dibandingkan non SSD. Rasio $\mathrm{Ht} / \mathrm{Hb}$ tertinggi dan terendah menunjukkan perbedaan yang sangat bermakna pada kasus SSD dan non SSD $(p=0,000)$.

\section{SARAN}

Penelitian pendahuluan ini perlu diikuti dengan penelitian lanjutan dengan jumlah kasus yang lebih banyak untuk dapat menentukan cut of point (batas untuk patokan) kenaikan $\mathrm{Ht}$ yang berisiko terhadap terjadinya renjatan pada DBD.

\section{DAFTAR KEPUSTAKAAN}

1. Hadinegoro SR, Soegianto S, Wuryadi S, Seroso T. Buku Tatalaksana Demam Berdarah Dengue di Indonesia. Dirjen PPM \& PL DEPKES. Jakarta. 2001.

2. Hadinegoro SR. Pitfalls \& Pearls. Diagnosis Tatalaksana Demam Berdarah Dengue. Dalam: Trihono PP, Sharif DR, Amir I, Kurniati N (penyunting). Pendidikan Kedokteran Berkelanjutan IKA XLVI Current Management of Pediatrics Problems. Edisi pertama. Departemen IImu Kesehatan Anak FKUI-RSCM. Jakarta; 2004: 63-72. 
3. Halstead SB. Pathophysiology and Patogénesis of Dengue Haemorrhagic Fever. In: Tongchaeron, ed. Monograph on Dengue/Dengue Haemorrhagic Fever. New Delhi: World Health Organization SEARO. Regional Publication; 1993; 22: 48-54.

4. Sutaryo. Dengue. Edisi pertama. Yogyakarta: MEDIKA Fakultas Kedokteran Universitas Gajah Mada; 2004.

5. Centres for Disease Control and Prevention (DCD). Dengue Clinical Manifestation and Epidemiology: Clinical Laboratory Analyzes in Hospitalizad Cases of DHF. Puerto Rico. 1990-1991.

6. Hadinegoro SR. Tatalaksana Demam Dengue/Demam Berdarah Dengue pada Anak. Dalam: Hadinegoro SR, Safari HI (penyunting). Demam Berdarah Dengue: Naskah Lengkap Pelatihan bagi Pelatih Dokter Spesialis Anak dan Dokter Spesialis Penyakit Dalam dalam Tatalaksana Kasus DBD. Jakarta:BP FKUI; 1999; 80-135. 